\title{
Inmotics: sustainability and comfort
}

\author{
Imnótica: sostenibilidad y comodidad
}

Domótica: sustentabilidade e comodidade

Fecha de recepción: 15 de marzo de 2017

Fecha de aceptación: 18 de agosto de 2017

Franz Wilhelm Strauch-Gómez

Diego Fernando Gutiérrez-Martínez*

Jose Fernando Martínez-Baquero ***

Rubén Darío Hernández-Beleño ${ }^{*+* * *}$

Baldomero Méndez-Pallares ${ }^{*+*+*}$

\section{Abstract}

The Olympic Games produce a long-lasting social, urban, cultural and economic impact in the host cities. For the specific case of the Youth Olympic Games, which will be held in the city of Buenos Aires, Argentina, a proposal has been selected to build an Olympic village that would function as social housing after hosting the games participants. Moreover, the International Olympic Committee requires and promotes the principle of environmental sustainability; consequently, host cities must adapt to host the event without losing sight of the optimal management of resources. In this context, technologies such as building automation become relevant and applicable to meet the objectives of providing quality of life and work without neglecting the efficient use of energy. Furthermore, this solution comes with great challenges that serve to promote the advancement of science and social commitment.

Keywords: Automation; Environmental sustainability; Green buildings; Inmotics; Olympics.

\section{Resumen}

Los juegos olímpicos tienen un impacto social, urbano, cultural y económico de larga duración sobre las ciudades que sirven de sedes. Para el caso específico de los juegos olímpicos juveniles, cuya sede será la ciudad de Buenos Aires (Argentina), se ha seleccionado la propuesta de construir una villa olímpica, que en un principio hospedará a los participantes de los juegos y luego se convertirá en vivienda de interés social. Por otra parte, el Comité Olímpico Internacional requiere y promueve el principio de sostenibilidad ambiental; por lo tanto, las ciudades anfitrionas deben adaptarse a celebrar los juegos sin dejar de lado el manejo óptimo de los recursos. Es en este contexto que tecnologías como la automatización de construcciones se vuelven relevantes, y pueden ser aplicadas para cumplir los objetivos de brindar calidad de vida y de trabajo sin ignorar el uso eficiente de la energía. Adicionalmente, este tipo de soluciones generan grandes retos que sirven para promover el avance de la ciencia y el compromiso social.

Palabras clave: Automatización; Comodidad; Inmótica; Olímpicos; Sostenibilidad.

* Universidad Piloto de Colombia (Bogotá-Distrito Capital, Colombia). fstrauch30@upc.edu.co. ORCID: 0000-0002-6164-8885.

** Universidad Piloto de Colombia (Bogotá-Distrito Capital, Colombia). diego-gutierrez1@upc.edu.co. ORCID: 0000-0001-5671-6655.

*** Universidad Piloto de Colombia (Bogotá-Distrito Capital, Colombia). jmartinez67@upc.edu.co. ORCID: 0000-0002-0752-9332.

****Ms. C. Universidad Piloto de Colombia (Bogotá-Distrito Capital, Colombia). ruben-hernandez1@upc.edu.co. ORCID: 0000-0001-8152-2633.

***** Universidad Piloto de Colombia (Bogotá-Distrito Capital, Colombia). baldomero-mendez@upc.edu.co. ORCID: 0000-0002-7960-0433. 


\section{Resumo}

Os jogos olímpicos têm um impacto social, urbano, cultural e econômico de longa duração sobre as cidades que servem de sedes. Para o caso específico dos jogos olímpicos juvenis, cuja sede será a cidade de Buenos Aires (Argentina), tem sido selecionada a proposta de construir uma vila olímpica, que em um princípio hospedará aos participantes dos jogos e depois se converterá em moradia de interesse social. Por outra parte, o Comitê Olímpico Internacional requer e promove o princípio de sustentabilidade ambiental; portanto, as cidades anfitriãs devem adaptar-se a celebrar os jogos sem deixar de lado o ótimo manejo dos recursos. É neste contexto que tecnologias como a automatização de construções tornam-se relevantes, e podem ser aplicadas para cumprir os objetivos de brindar qualidade de vida e de trabalho sem ignorar o uso eficiente da energia. Adicionalmente, este tipo de soluções geram grandes desafios que servem para promover o avanço da ciência e o compromisso social.

Palavras chave: Automatização; Comodidade; Domótica; Olímpicos; Sustentabilidade. 


\section{INTRODUCTION}

Within the framework of the Olympic Games movement, Argentina won to host the 2018 Olympic Youth Games. To achieve this, Buenos Aires city has been involved in a changing process to perform well and be the right place to host an event of such magnitudes.

Since 2000, the International Olympic Committee (IOC) has promoted an ethical and socioeconomic commitment to sustainability [1]. Consequently, the Olympic Games encourage the development of abilities and actions that promote environmental and social progress by designing innovations, new buildings, and better strategies to manage resources such as the energy. Therefore, the places chosen to host the Olympics must meet such conditions.

Thereby, the cities hosting the Olympic Games have gone through a process of total transformation, which includes the design and renovation of the urban architecture and the implementation of new technologies. It is worth making a brief recount of the models according to which the cities have been adapted for the occasion.

The Olympic Games that took place close to World War I (London 1908, Stockholm 1912, Ambers 1920, Paris 1924 and Amsterdam 1928) did not make great impact in the host cities. These cities offered an urgent and temporary model to resolve the lodging problem. The first Olympic village was built in Los Angeles to receive the 1932 games; the next Olympic village was built in Berlin for the 1936 games. Both villages established a basic model that would be implemented during the next two decades: "a multifunctional structure, besides the lodging and support for athletes, [included] equipment as areas for training, resting, and body care, as well as recreational areas" [2].

It was during the 60's, in Rome (1960) and Mexico (1968), when the Olympic villages stopped being just a temporary lodging to start being conceived as projects of urban expansion and residential zoning. This model was used in cities like Moscow (1980), which contemplated an Olympic village in its development plan, and Seoul and Barcelona, which appropriated the 'Olympic urbanism' to renovate important urban pieces. In opposition to those models, Los Angeles (1984) and Atlanta (1996) did not build
Olympic villages; instead, they employed buildings that had previously hosted the participants [3].

At the beginning of the new millennium, the Olympic village design started to have the characteristics of the urban trends of the period: the need to ensure safety and address concerns about environmental sustainability. Francesc Muñoz states that the building of Olympic villages in the XXI century was inspired on what was considered an ideal city and an ideal urban region [4]. Accordingly, cities like Sidney (2000) and Athens (2004) built their Olympic villages following a sustainable model, and Beijing (2008) attended the technological needs of the communication sector linked to ecological sustainability; the model presented by London (2012) and Brazil (2016) was characterized by the propose of urban expansion following sustainability models and pursuing a technological vanguard.

Therefore, the games have been seen from a perspective in which they serve their host cities by catapulting them to change through the execution of urban projects and social inclusion; hence, their impact is long lasting. Buenos Aires city can be seen under this conjuncture, since an 'Olympic village neighborhood' is planned as a place to host the athletes and, eventually, a site for social housing [5]. In this way, the design should respond to the needs of both the athletes and the people who will live there when the event ends.

The Olympic village that will temporarily host the games participants, and that later on will serve as a permanent house for families currently located in the 'Comuna 8' in the 'Villa Soldati' neighborhood should follow the XXI century models, according to the IOC mission and task. The village must be designed and equipped to be environmentally sustainable and to adequately manage the resources. In addition, due to its housing function, it should represent comfort, functionality and quality of life. Such objectives can be achieved if the technologies that meet the needs of the inhabitants while saving and optimizing resources are employed.

\section{Materials AND Methods}

In the mentioned reality, a question appears: What or which technologies are suitable for planning and building a place that complies with the above? This 
article aims to argue that inmotics, as a technology to control comfort and security functions in buildings and as a tool for saving energy, is a fundamental instrument to achieve the objectives of the Olympic village in the 'Comuna 8' located in Buenos Aires city; indeed, inmotics can work as an element for social inclusion because it improves the quality of life of the citizens with low purchasing power.

To support this position, theoretical and practical researches from other authors have been taken as the fundamental basis for this article. For this reason, first, we searched, selected and reviewed primary sources on inmotics, in order to recognize the benefits and feasibility of inmotics installations. Subsequently, we compiled the ideas related to the general objective to argue the pertinence of using inmotics in buildings that represent energy saving and provide comfort. Finally, we collected the most important results and elements for discussion.

\section{WHAT IS INMOTICS?}

The literature review on the inclusion of technologies in buildings for domestic and industrial uses showed that, at the end of the XX century a trend of designing and implementing tools and strategies to save energy began; this implementation started in buildings for industrial uses. It is argued that this trend began because those types of buildings accounted for $40 \%$ of the worldwide energy consumption, besides being main contributors to the greenhouse effect [6-10]. With this situation, awareness for the sustainability of the environment began to rise until legal precepts were given in the European Union and the United States to demand that buildings were energy efficient [11-12].

To respond to this problem, inmotics systems were developed. Inmotics is a network technology conceived to make a smart employment of the energy, with the final objective of mitigating the environmental impact, optimizing resource consumption and reducing costs. Inmotics extends as an automated system that in an optimal and integrated way gives the possibility of controlling, monitoring, managing, and keeping the devices in charge of the building's operation [13-17]. This technology allows to control and supervise all its components from a single platform; in fact, the system management is centralized. However, inmotics systems are only installed in industrial buildings [1823].
Apart from the emphasis placed on regulating energy consumption, the reviewed literature also shows that inmotics is related with the user's comfort and security. On one hand, it has been proved that the higher the comfort, the higher the productivity rates; therefore, a quality of work is achieved. Consequently, the inmotics technology has two fundamental objectives: optimize the energy consumption using automated and integrated applications, and keep the users comfortable.

Among the essential functions that must be integrated into an inmotics system are illumination, heating, ventilation, air conditioning and water supply, as well as monitoring the safety alarms for fires, gas leaks, etc., registering personnel, and controlling the sound system, elevators and engines such as water pumps, exhausters, etc. Nonetheless, the elements covered by the system always depend on the users' needs and the building characteristics; hence, the conformation of the inmotics systems will be different in each situation, but its characteristics will be the same.

There is a consensus on the fundamental features of the inmotics systems:

- Integration: the inmotic system is something more than an automated system because, although autonomous, its agents do not perform in isolation; therefore, the building is equipped in a way that all subsystems answer adequately to the environment and the requirements of the workers.

- Flexibility: the system must be able to incorporate new subsystems or agents without inconvenience, and to carry out relevant updates.

- Scalability: the system should work in both small and large buildings.

- Adequate response times: the system must response promptly to the user's requirements and the circumstances of the controlled environment.

- Modulation: the system must be able to independently manage each area connected to its network.

- Reliability: the system's design must generate the least margin of error.

- Simple operation: the system has the possibility of being operated by people with common knowledge, not necessarily by engineers, so it must be easy and fast to understand. 
- Remote control: the system can be operated by wireless devices with mobile technology that allows communication from anywhere.

A inmotic system is a network that controls, supervises and optimizes devices and agents in charge of managing different building areas; thus, each component performs its function automatically without leaving the centralized control. In this way, the buildings become smart buildings because they employ high technology to control their functioning in an automatic and integrated way; thereby, they promote a productive environment and allow the efficient management of resources.

\section{A. Challenges of Inmotics}

The inmotics imperative challenge consists in achieving an efficient use of energy without neglecting the users' comfort; to achieve this, the system must be dynamic. "If you want to reach substantial savings in energy consumption, static assumptions are not enough. Besides, you must consider the presence or absence, the activity and [the] behavior of the users" [24]. Thus, the inmotics systems must be smart enough to, for instance, recognize that nobody is in a uselessly illuminated sector or that the natural light levels do not justify bulbs at high levels of intensity; similarly, the system must be able to adjust the heating depending on the ambient temperature, to turn off the electronic devices when nobody is using them and to close the water tap when necessary; additionally, it must have the capacity to recognize an intruder or to program the office environment according to the schedule and the needs of the users. The inmotics systems must interpret the users' preferences and act automatically according to them; also, they must be able to predict what the building workers are going to require. "In this case, we are talking about systems that must be designed to act appropriately in changing, unforeseen and complex situations" [25].

If an inmotics system must offer multiple possibilities, the challenge consists in achieving the integration of each application in the same communication network. The research regarding this topic is extensive [2634]. Every electronic device in charge of the building operation must be interconnected to the centralized management, in order to share their abilities to perform activities beyond their individual capacities [35]; therefore, there are more than one agent interacting in a shared environment.

The system is optimal when each component speaks the same language and is compatible with all the others. The inmotics network must be based on communication protocols to ensure that each control component is able to send its message and exchange consistently the information [36]. The inmotics systems are primarily composed by the following elements: a set of sensors, controllers, and agents that allow to interact with the medium and to automate the building; one or many devices with information processing capacities to manage the set of sensors, controllers, and agents; a transmission medium and a communication protocol, through which each element of the system exchanges data; and an interface that allows the user to know the status of the installation.

Therefore, the network of an intelligent building is composed of two essential parts: 1) the internal network, properly inmotics, which constitutes the communication, control, and management of the component in charge to interact with the environment to control; 2) the external network that provides information from the outside. In order to smartly automatize a building, the sensors should gather information from the environment, and send the data to the control system; those messages must be compatible and able to adapt to the controller. Once the controller processes the information, it sends fit orders to the agents in charge of each integrated function. Hence, the foundation of inmotics is the communication: the transmission of data in order to control and manage the automated operation of the building.

Thence, the biggest challenge faced by designers of inmotics networks is to develop or apply communication protocols, so the network can function effectively, otherwise, the building would just be an automated installation. The more complex the system, the harder it will be to make all elements speak the same language. This is where the great field of study of inmotics resides; here it can be recognize a long way yet to go to reach a standardized measure for communication in inmotics systems. For this reason, [37] describes that a smart building can be made of integrated systems with capacity to achieve a constant communication and data storage of operative mode from the environment around the home or industrial automation. 


\section{B. Inmotics benefits}

The installation of an inmotics network entails a reduction of energy consumption, thus reducing costs and contributing to care for the environment; additionally, it increases the comfort because is programmed and updated according to the users' requirements without losing sight of the energy management; it gives security, protects confidential information and provides surveillance services; and it can be managed remotely through the internet. All of the above gives an extra value to the building. Furthermore, the imnotics field encourages the field of technological research to generate new protocols that will play a standard role in the communication networks between devices arranged for control.

\section{INMOTICS AND DOMOTICS}

The literature review revealed that inmotics is inherently related to domotics, since no research exclusively focused on inmotics. The fundamental difference between these two technologies is that imnotics is developed for industrial buildings, whereas domotics is designed for domestic buildings; thus, the first aims at job quality and the second at quality of life [38-45].

On the other hand, inmotics is fundamentally an integrated and automated system, while domotics appears only as an automated system. A domotics system can be automated without being integrated, on the other hand, if an inmotics system is not integrated, the building where it is installed cannot be smart. Therefore, the communication problems inside a smart network are sometimes necessaries for the development of inmotics, with adaptations contingent of applications that are used in domotics.

\section{Discussion And Results}

- Given the importance of the Olympic village project, it is pertinent to install a system that controls and manages the building operations, and that optimally uses the resources. Through an inmotic network, the building can satisfy needs like proper temperature, enough lighting and heating, security alarms, hot water control, telecommunications management, and schedule adaptations, among others; at the same time, the system guarantees the conservation principle and the sustainability of the environment.

- A smart Olympic village represents a place capable of updating, adapting, and setting up itself, according to the athletes' requirements; besides being a space that provides comfort to the athletes' daily activities. Due to its flexibility, integrity and simple operation, the inmotics technology should be considered in the design of buildings for hosting large number of people with special requirements for their accommodation. Thus, the building would be able to receive the Olympic Youth Games' participants, while complying with the IOC sustainability principle.

- Now, it has to be said that the village design must consider that after the games it will be a place for social housing. In this specific case, the inmotics and domotics are related because both aim at users' comfort and energy saving. However, issues emerge when one system has to be coupled to the other; ergo, when the network must be modified. The solution to this can be based on the flexibility of the inmotics system, which can integrate other agents, and control and update the devices.

- Furthermore, it is important to focus on the integrity of the inmotics network because the houses with those installations must control efficiently all the systems from a single platform. This aspect is not necessarily considered in a domotics network. Nevertheless, the inescapable challenge emerges: if adjustments have to be made to meet the needs of the inhabitants after having rendered the services to the athletes, the attached devices must be compatible with the system's communication network.

- On the other hand, we cannot left aside the fact that inmotics installations require an economic investment higher than the budget disposed for only social housing; therefore, one of the challenges consists in matching as much as possible the services required by both athletes and future residents. Consequently, an interdisciplinary design will be necessary for the building, in order to respond to the specific needs of the people; and a strategy should be found to avoid big changes in the installed network as a result of the different uses, which could increase costs or prevent the system to work in all its potential, 
- The installation of inmotics in houses greatly benefit the habitants because it provides comfort and quality of life; thus, people with low purchasing power, such as the families that access social housing, can stop seeing these tools as a luxury and start taking them as easy strategies to improve their everyday life and contribute to the sustainability of the environment [46-50].

\section{Conclusions}

- The reviewed literature on inmotics revealed that this technology seems to be an ideal solution for smart and sustainable building projects, because it contributes to the efficient use of resources, and attends the users' needs. Therefore, inmotics supply an automated system that controls, monitors, manages and maintains, in an optimal and integrated way, the devices in charge of the building's operations to serve the users. Accordingly, it is recognized that the main challenge of these systems is the efficient use of energy without neglecting the comfort of the users.

- Thereby, the inmotics network is as a pertinent strategy for designing the Olympic village with the necessary characteristics to host the games participants in articulation with the principle of environmental sustainability. The Olympic village buildings must work as an automated home that represents quality of life, while managing and controlling the resources, for families with low purchasing power who will receive the benefit of having the opportunity to access a housing of social interest.

- The development of new technologies that allow network connectivity is becoming more popular; in fact, the evolution of the internet will generate different opportunities for the development of applications of all kinds. In this case, thanks to the new technologies for automation, it is possible to control the different devices at home. The current concern about global warming and depletion of natural resources present new and paramount challenges for implementing technologies aimed at helping conserve resources and promoting awareness on energy consumption in buildings and homes. With this technology, the user can simultaneously control the home and observe the electrical consumption, with the possibility of turning off the different devices controlled remotely.

- Because communication technologies evolve at the same time as the global internet network, there are many opportunities for designing new platforms for immobile systems; in this case, for the development of Olympic villages whose ultimate goal is to be houses of social interest that allow residential control. Furthermore, with the technology called "Internet of Things", the connectivity between devices will be complete, allowing to connect not only houses but cities and countries, with the possibility of developing interfaces for the management and control of smart cities.

\section{REFERENCES}

[1] O. Charter, T. Strategy, C. UN, S. Sport, and S. Game, "Sustainability," International Olympic Committee, 2017. [Online]. Available: http://www.olympic.org/ sustainability. [Accessed: 14- Aug- 2017].

[2] F. Torres, "Territorio y lugar: potencialidades para el análisis de la construcción de sujetos políticos, el caso de un movimiento de desocupados en Argentina," Geo Graficando, vol. 7, 2017.

[3] E.Fernández, B. Cerezuela, M. Gómez, C. Kennet, and M. De Moragas, Mosaico Olímpico, Ayuntamiento de Barcelona y centro de estudios olímpicos de la Universidad Autónoma de Barcelona, 2011.

[4] Normativa de Domótica en Inmótica", Cedom. es, 2017. [Online]. Available: http://www.cedom. es/sobre-domotica/normativa-y-certificacion. [Accessed: 18- Aug-2017].

[5] G. Palese, "Larreta busca guiños internacionales para culminar la Villa Olímpica," Letra P, 2017. [Online]. Available: http://www.letrap.com.ar/nota/2016-4-15larreta-busca-guinos-internacionales-para-construirla-villa-olimpica. [Accessed: 18- Aug- 2017].

[6] E. Sosa, D. Godoy, E. Belloni, J. Benítez, and M. Sosa, "Eficiencia energética y ambientes inteligentes. Investigación y desarrollo experimental en la UNaM," in XVII Workshop de Investigadores en Ciencias de la Computación 2015, Universidad Nacional de Salta, Argentina, 2015.

[7] T. Nguyen, and M. Aiello, "Energy intelligent buildings based on user activity: A survey," Energy and Buildings, vol. 56, pp. 244-257, 2013. DOI: http://doi.org/10.1016/j.enbuild.2012.09.005.

[8] F. Nizamic, T. Nguyen, and A. Lazovik, "Green Mind - An architecture and realization for energy smart building," in Proceedings of the 2nd International Conference on ICT for Sustainability, Stockholm, Sweden, 2014. 
[9] Hou, Y. Liu, Y. Wu, N. Zhou, and W. Feng, "Comparative study of commercial building energyefficiency retrofit policies in four pilot cities in China," Energy Policy, vol. 88, pp. 204-215, 2016. DOI: http://doi.org/10.1016/j.enpol.2015.10.016.

[10] A. Ghaffarianhoseini, U. Berardi, H. Al Waer, S. Chang, and E. Halawa, "What is an intelligent building? Analysis of recent interpretations from an international perspective," Taylor \& Francis, 2017. [Online]. Available: http://www.tandfonline. com/doi/full/10.1080/00038628.2015.1079164. [Accessed: 18- Aug- 2017].

[11] O. Querol, "Ahorro y eficiencia energética con Domótica e Inmótica," Inmueble, Revista del sector inmobiliario, vol. 159 (2335-5573), pp. 38-43, 2016.

[12] R. Lempert, N. Nakicenovic, D. Sarewitz, and M. Schlesinger, "Characterizing ClimateChange Uncertainties for Decision-Makers. An Editorial Essay," Climatic Change, vol. 65 (12), pp. 1-9, 2004. DOI: http://doi.org/10.1023/ B:CLIM.0000037561.75281.b3.

[13] J. Borggaard, J. Burns, A. Surana, and L. Zietsman, "Control, estimation and optimization of energy efficient buildings", in Proceedings of the American Control Conference (ACC '09), St. Louis, Missouri, USA, 2009, pp. 837-841. DOI: http://doi.org/10.1109/ ACC.2009.5160552.

[14] M. J. Bounzas, "Panorámica de los sistemas domóticos e inmóticos," Thesis Grade, Departamento de Ingeniería de Sistemas y Automática, ingeniería en Telemática, Escuela Superior de Ingenieros, 2005.

[15] M. Errecalde, M. Lasso, A. Villagra, D. Pandolfi, and M. de San Pedro, "Edificios inteligentes: el enfoque multi-agente," in VIII Workshop de Investigadores en Ciencias de la Computación: Red de Universidades con Carreras en Informática (RedUNCI), Buenos Aires, Argentina, 2006.

[16] I. Constantino, "Domótica e inmótica: viviendas y edificios inteligentes," Thesis Grade, Universidad Veracruzana: Facultad de Ingeniería Mecánica Eléctrica, 2011.

[17] C. Romero Morales, F. Vázquez Serrano, and C. Castro Lozano, Domótica e inmótica. México: Alfaomega, 2011.

[18] A. Gutiérrez, "La inmótica como garantía de una infraestructura eficiente," Dínamo técnica: revista gallega de energía, vol. 16, pp. 22-23, 2015.

[19] V. Moya, Diseño de una aplicación inmótica en el edificio Carlos Crespi de la Universidad Politécnica Salesiana en la ciudad de Cuenca - Ecuador, Universidad Politécnica de Madrid, 2012.

[20] Arias, "Inmótica arias total," 2017. [Online]. Available: http://es.slideshare.net/ChichiArias/ inmtica-arias-toral. [Accessed: 18- Aug- 2017].

[21] H. Domínguez, and F. Sáez, "Domótica: Un enfoque sociotécnico," Universidad Politécnica de Madrid, 2006.
[22] O. Buitrago, O. Palacio, R. Brito, and W. Adarme, "Propuesta metodológica para la selección de la configuración de centros de distribución inmóticos utilizando análisis envolvente de datos Ingeniare," Revista chilena de ingeniería, vol. 24 (0718-3291), pp. 480-492, 2016.

[23] J. Torres, La inmótica en un planteamiento para la aplicación de la tecnología en un entorno físico arquitectónico y urbanístico para potencializar la inclusión en campus educativos. Estudio de caso: documento diagnóstico estado actual y recomendaciones de accesibilidad en la Universidad Nacional de Colombia, DDRASUN Universidad Nacional de Colombia.

[24] E. Sosa, "Evolución Tecnológica e Internet del Futuro", in XIV Workshop de Investigadores en Ciencias de la Computación, Buenos aires, Argentina, 2012.

[25] M. Errekalde, Estudio de mercado Sector de la Domótica e Inmótica. Madrid España: Asociación Española de Domótica, 2015.

[26] A. Fonseca, M. Barrera, J. Carvajal and N. Londoño, "Análisis y diseño de un prototipo de sistema domótico de bajo costo," Revista Facultad de Ingeniería Universidad de Antioquia, núm 63, pp. 117-128, 2012.

[27] F. Leal and M. Hernández, "Implementación de protocolos inteligentes de comunicación y control generando nuevas soluciones en automatización y sistemas de domótica e inmótica," in $V$ Congreso Iberoamericano de estudiantes de ingeniería eléctrica - CIBELEC, Neiva, Colombia, 2012.

[28] H. Paz, G. Castellanos, R. Alarcón, V. Weiss, A. Laverde, J. Rodríguez and L. Rincón, "Automatización del laboratorio de ingeniera electrónica G-204 de la ECCI a través de una red inmótica," Revista Ingeniería e Investigación, vol. 26, pp. 100-112, 2006.

[29] M. Sisti, J. Rapallini, W. Aróztegui and A. Quijano, "Red de sensores inalámbrica," in Terceras Jornadas de Investigación, Transferencia y Extensión, Universidad Nacional de la Plata, pp. 313-316, 2015.

[30] G. Souza, F. Vieira, C. Lima, G. Deus Júnior, M. Castro, S. Araujo and T. Vasquez, "Developing Smart Grids Based on GPRS and ZigBee Technologies Using Queueing Modeling-Based Optimization Algorithm," ETRI Journal, vol. 38 (1), pp. 41-51, 2016. DOI: http://doi.org/10.4218/ etrij.16.0114.0971.

[31] F. Falcone, Domótica e inmótica: instalaciones de telecomunicaciones para edificaciones. Bogotá: Alfaomega Mega, 2016.

[32] C. Bonilla, and A. Hidalgo, Diseño e implementación de un sistema de video vigilancia, control de iluminación y comunicación de mensajes para la 
Biblioteca de Ingeniería Eléctrica y Electrónica. Quito: EPN, 2013.

[33] N. Olivia, M. Castro, G. Diaz, F. Mur, R. Sebastián, and E. San Cristóbal, Redes de comunicaciones industriales. Universidad Nacional de Educación a Distancia, 2013.

[34] V. Pérez, Plataforma de comunicación LAN/WAN con uso de microprocesadores para la aplicación en áreas de domótica e inmótica. Medellín: s.n. 2010.

[35] A. Brandt, K. Samuelsson, O. Toytari, and A.L. Salminen, "Activity and participation, quality of life and user satisfaction outcomes of environmental control systems and smart home technology: a systematic review," Disability and Rehabilitation: Assistive Technology, early online, pp. 1-18, 2010.

[36] C. Romero, Domótica e inmótica: viviendas y edificios inteligentes, México: Alfaomega Mega, 2011.

[37] J. Bounzas, Panorámica de los sistemas domóticos e inmóticos, Trabajo de graduación, Universidad de Sevilla, 2005.

[38] J. Sarasua, "Domótica, un factor importante para la arquitectura sostenible," Revista Módulo, vol. 1, pp. 267-277, 2011.

[39] M. Jahn, M. Jentsch, C. Prause, F. Pramudianto, A. Al Akkad, and R. Reiners, "The energy aware smart home," in V International Conference on Future Information Technology, Busan, South Korea, 2017.

[40] A. Cyril Jose, and R. Malekian, "Smart Home Automation Security: A Literature Review," The Smart Computing Review, 2015.

[41] L. Anido, C. Rivas, M. Gómez, S. Valladares, and M. Fernandez, "Improving the quality of life of dependent and disabled people through home automation and tele-assistance", in 8th International Conference on Computer Science \& Education, Sri Lanka, 2013.

[42] M. Zamora-Izquierdo, J. Santa, and A. GomezSkarmeta, "An Integral and Networked Home
Automation Solution for Indoor Ambient Intelligence," IEEE Pervasive Computing, vol. 9 (4), pp. 66-77, 2010. DOI: http://doi.org/10.1109/ MPRV.2010.20.

[43] A. Matos, Diseño de sistemas activos para viviendas de carácter social en el trópico caribeño, Master of Science, Universitat Politècnica de Catalunya: Escola Politècnica Superior d'Edificaciò de Barcelona, 2016.

[44] B. Quintana G., V. Pereira Poveda, and C. Vega S., "Automatización en el hogar: un proceso de diseño para viviendas de interés social," Revista EAN, no. 78, p. 108, 2015.

[45] M. Joly, "Universal accessibility: Domotics," Annals of Physical and Rehabilitation Medicine, vol. 54, pp. 58, 2011. DOI: http://doi.org/10.1016/j. rehab.2011.07.778.

[46] Asociación Española de Domótica e Instituto para la diversificación y ahorro de Energía, Cómo ahorrar energía instalando domótica en su vivienda, gane en confort y seguridad, 2008. [Online]. Available: http:// www.cedom.es/fitxers/documents/publicacions home/Guia\%20de\%20Ahorro\%20Energetico $\% 2 \overline{0}$ CEDOM.pdf. [Accessed: 18- Aug- 2017].

[47] A. Vega, F. Santamaria, and E. Rivas, "Modeling for home electric energy management: A review," Renewable and Sustainable Energy Reviews, vol. 52, pp. 948-959, 2015. DOI: http://doi. org/10.1016/j.rser.2015.07.023.

[48] E. Batov, "The distinctive features of "smart" buildings," Procedia Engineering, vol. 111, pp. 103-107, 2015. DOI: http://doi.org/10.1016/j. proeng.2015.07.061.

[49] M. Barrera, "Domótica e inmótica: visión general y actualidad," Revista AIE UdeA, pp. 13-19, 2011.

[50] G. Toschi, L. Campos, and C. Cugnasca, "Home automation networks: A survey," Computer Standards \& Interfaces, vol. 50, pp. 42-54, 2017. DOI: http://doi.org/10.1016/j.csi.2016.08.008. 